\title{
Milpa or Forest. Development Crunch in the Most Marginalized Communities in the State of Hidalgo (Mexico)
}

\author{
Tomás Serrano*, Emmanuel Galindo, Tomás Hernández \\ Instituto de Ciencias Sociales y Humanidades, Universidad Autónoma del Estado de Hidalgo, Pachuca, México \\ Email: "tomass@uaeh.edu.mx
}

Received 7 January 2016; accepted 14 February 2016; published 17 February 2016

Copyright @ 2016 by authors and Scientific Research Publishing Inc.

This work is licensed under the Creative Commons Attribution International License (CC BY).

http://creativecommons.org/licenses/by/4.0/

(c) (i) Open Access

\begin{abstract}
In the world, only a few decades ago, human progress based on the consumption of energy from fossil fuels has pushed us to accept it as the cause of global warming. This problem will continue due to an unbalance of the environment, originated by the increase of $\mathrm{CO}_{2}$ via consumption of fossil fuel, added to the decrease of $\mathrm{O}_{2}$ in the air due to the growth of desertification. The article is a lesson to the study of global warming. In Mexico, at the local level, the richest region in biodiversity in the state of Hidalgo is becoming a desert by the performance of the main economic activities of the population. In sum, the damage in such a way at the region Otomi Tepehua, wide desert areas will become visible; nevertheless, current conditions of rainfall still take place, which could worsen life conditions for its population; increasing poverty among it, due to the direct decrease in the amount and quality of milpas. Moreover, water and oxygen decrease will impact negatively on the majority of population located in the center of Mexico.
\end{abstract}

\section{Keywords}

Environment, Global Warming, Sustainable Development

\section{Introduction}

Until just a few decades, the concern for the environment grew in an unusual way since this issue has been considered a priority global problem to which the society, as a whole, has had to face to counter global warming [1]. The review of available information can be framed insustainable development, since this concept brings together the knowledge that seeks to make compatible the economic growth with the care for the environment.

${ }^{*}$ Corresponding author.

How to cite this paper: Serrano, T., Galindo, E. and Hernández, T. (2016) Milpa or Forest. Development Crunch in the Most Marginalized Communities in the State of Hidalgo (Mexico). Journal of Water Resource and Protection, 8, 201-210. 
The first antecedent of sustainable development, conceived from the term human ecology, began in the decade of 1920 in the Chicago School [2].

By this way, there is a consensus to point out that the damage to the environment is difficult to measure quantitatively; but easily seen qualitatively, and which result is an ethical problem with only two options: we all add or we all lose [3] [4].

Since some decades ago, several academics agree on the need to pronounce ecological, technological, economic and cultural processes, taking as starting point the real existence of the supremacy of economic interests, subordinating the rest of values [5]-[8]. That is, the articulation is complex, precisely because we live in a world subject to the power of the economy, in which there is concentration of wealth, growth of inequality and which generates unsustainability [9].

The hypothesis of our work argues that the main economic activities of the population and the social changes are reducing sustainable ecological systems in the Otomi-Tepehua region in the State of Hidalgo.

To this end, our work is based on official data which contextualize the main socioeconomic characteristics of the study region; in terms of population; marginalization; human development index; area sown to corn, beans, trees and coffee.

To begin with, we have to make three clarifications. Firstly, our observation parts of the project developed in 2014, in the Center for Studies on Population, in which the potential of development was investigated in 20 locations of high marginalization in the State of Hidalgo. Based on data from the National Council on Population 2010, 80\% of the 20 most marginalized towns in Hidalgo were placed in order of importance in the municipalities of San Bartolo Tutotepec, Huehuetla and Tenango de Doria. Secondly, a product of direct observation where we found that the greatest wealth of these political divisions is the generation of water and oxygen; and finally, we conclude that in this region lowland and forest trees are at risk due to corn and beans growing on steep slopes, asituation in which we predict that the first deserts will appear approximately in 30 years in the area of the highest biodiversity of this entity.

\section{Environment and Population}

Works, such as Ponting's [10], are a mandatory reference to the study of sustainable development. He suggests that social change is a catalyst that affects the physical environment. The author offers a full view of the rise and fall of civilizations, including the Sumerians, Egyptians and Mayans. Thus, Ponting recognizes, as in the present, every society has had major effects on the environment, with respect to their predecessors. In his study, he highlights the emergence of settled societies, whose common distinction has been poverty. Based on current trends, characterized by the growth of the population and the availability of scarce resources, this author predicts a bleak future for humanity.

In his A New Green History, Ponting observes Easter Island (Chile), a territory where he found a tiny indigenous population of Polynesian origin, crowded and miserable, while most of its territory was used for breeding sheep. The lesson to draw is clear, in this place, better than any other, the land revealed the limited resources that it has to support the population and its demands; so, when, in a given period, society terminates with the available resources, there is no way to overcome the limits that nature offers. As the main point, he insists -The various forms of life on Earth, including humans, are part of ecosystems. Their existence is based on photosynthesis, whether in tropical forests, grasslands, meadows, coral reefs, and so on; that is, the photosynthesis process is the basis that supports life, as it is the only way that energy is integrated in biotic systems. Precisely here lies its importance: the existence of the forest on the mainland is a priority over anything.

Likewise, the author illustrates historical lessons of civilizations, where he estimates that about 6000 before Christ, in Jordan, the agricultural society, after a period of a thousand years of sedentary settlement, villages began to be abandoned because of soil erosion, and this, in turn, was due to deforestation, a similar process which took place in the booming of Asian societies settled in Mesopotamia, the Indus Valley, China, Mongolia and Japan, a few years later.

With this observation, it is clear that the world has faced a series of interrelated crises caused by past actions, characterized by similar problems such as deforestation, erosion, desertification, salinization, the increasing loss of lives and wild plants, and the unequal distribution of food.

Lakshmana, in his study in India, assessing the impact of demographic pressure on the environment, confirmed the existence of a close relationship in both variables, since, in regions of higher economic development 
of this country environmental damage is greater, in comparison to less developed regions [11]. For this purpose, the author segmented that nation into six regions, taking as the dependent variable the degree of land degradation, water and air on two types of explanatory variables: 1) proximate indicators such as population growth, density population and poverty; and 2) recent indicators such as urbanization, industrialization and economic development.

In such arrangement, the degree of environmental pollution in India indicated significant regional socioeconomic differences, depending on their characteristics. In this place, territories of more economic development, such as the North, West and South presented greater damage to the environment, with respect to the poorest regions such as Central, East and Northeast; places where the past still retains large tracts of forest. Additionally, in this evaluation, two variables transcended for their greater explanatory effect: population growth and economic growth.

On the other hand, Spierenburg and his colleagues [12], in his study at the National Park Jigme Singye Wangchuck of Bhutan, observed that with livestock intensification and with the change in agricultural crops, the forest can be saved; taking advantage for this purpose, soil regeneration and water generation to ensure the production of new crops such as rice, fodder, sugar cane and peanuts, citrus for local consumption; with the improvement of livestock, species were concentrated in barns, whose portion of used land was lower.

In the past, residents (about 5000 people), indiscriminately cut down trees to plant corn and millet, they had abundant grazing cattle in large pastures. The animals were used as draft animals.

According to polls, the population was aware that the forest was in danger, that the grazing cattle and agriculture had a negative impact, as many species were replaced by more resilient and more harmful ones to the biodiversity. However, the population grew and land pressure was increasing with the growing demand for agricultural land and cattle raising.

Faced with this dilemma, the research team proposed to intervene and organize land use, forest conservation and respect the development of the main economic activities of the residents.

In 1999 the intervention was initiated. The starting point was to demand that the forest had to be reduced. However, in practice, it was decided to do the opposite; that is, implementing a proposal for conservation and forest growth by reducing the land dedicated to livestock and agriculture. Therefore, livestock was integrated into stables, fodder was grown to feed it and corn crop growing was changed for rice cultivation. In the short term (4 years), it became evident that the results indicated that the forest preservation had contributed to the improvement of the household economy, increasing production in agriculture and livestock, providing water for irrigation and soil fertilization.

Today, in this place rice is grown in terrace systems, fodder for the cattle improved by crossbreeding with a more productive cattle breed, there is abundance in citrus production, which are consumed in the local market, the land is nitrogenized by the dragging of water from the forest, with a crop rotation of sugar cane and peanuts, as the first product deteriorates the quality of land and the last enriches it.

Tetreault, in his multidimensional study in Non-Governmental Organizations, in towns of Ayotitlán and La Cienega (Jalisco, Mexico), suggests that environmental movements have the potential to drive the structural changes needed to overcome poverty and environmental degradation [13]. Therefore, with the emergence of organizations, including those born under the Institutional Revolutionary Party model, in the rural Mexico violence and environmental damage caused by mining and forestry companies stopped; Above all, it is understood that, with the support of the University of Guadalajara, considering that with its intervention it created the Biosphere Reserve of the Sierra de Minatitlan. With this option, in a collective agreement, the preservation of scarce resources in this region of western Mexico was assured. The result of the study is clear: there must first be a local organizational infrastructure to build the effort to preserve the environment; second, the university has a responsibility to integrate the organizations in order to empower their territory. It seems that there is no other better way, without organization or local awareness the preservation of biotic resources is not possible.

\section{General Characteristics of the Otomi-Tepehua Region}

In this section we will discuss some important social characteristics of the Otomi-Tepehua region, since, based on indicators of population, marginalization, human development, economy, production of corn, beans and coffee and local reforestation efforts we expect to explain how the development of the main economic activities impact on the environment. 
In 2010, according to the number of inhabitants, the 3 municipalities of the Otomi-Tepehua region are small. In this regard, according to estimates by the National Population Council, given the growth rate in 2030, its population will increase to relatively at low levels, because until 2030 there will be an annual average of sustained growth of $1.7 \%$ (see Table 1 ).

According to the marginalization index of the National Population Council (CONAPO), in 2010, the municipalities of the region are at a high level, a difficult situation to reverse despite the investment in health care and development programs, including of course the program "Sin Hambre". In the same vein, the Human Development Index stands at lower average levels due to high infant mortality and low per capita income of local residents. Both data glimpses a complicated scenario in the study region, a place that in the coming years, little progress in social development will be seen (see Table 2).

The marginalization index is prepared by the National Population Council (CONAPO) since 1993. It takes into account 9 percentage indicators: occupants in private homes without running water, occupants of private homes without toilet or drain; occupants of homes with dirt floors, occupants of private homes without power, occupants of private homes with level of overcrowding, the illiterate population 15 years of age and older, the population 15 years of age and older with incomplete primary, the population living in localities of less than 5,000 inhabitants and the employed population earning up to two minimum wages.

The Human Development Index (HDI) was proposed by the United Nations Development Program (UNDP) since 1990. This indicator seeks to operationalize the concept of "capabilities" of Amartya Sen and takes into account 3 important components on average: the life expectancy, schooling, and income.

As for its economic base, as seen in Table 3, the Otomi-Tepehua region has a high specialization in the tertiary sector, a situation that characterizes its economy as vulnerable, because this productive sector does not generate wealth.

Table 1. Population and population growth rate in the Otomí-Tepehua region, 2010-2030.

\begin{tabular}{ccccc}
\hline & Population 2010 & $\%$ & Population 2030 & $\%$ \\
\hline Otomí-Tepehua Region & 58,906 & 0.9 & 68,923 & 1.7 \\
Huehuetla & 23,563 & 0.59 & 27,450 & 1.9 \\
Tenango de Doria & 18,137 & 1.9 & 20,807 & 1.2 \\
San Bartolo Tutotepec & 17,206 & 0.36 & 20,666 & 1.8 \\
\hline
\end{tabular}

Own calculations based on data from the Consejo Nacional de Población, 2010.

Table 2. Degree of marginalization and human development in the Otomí-Tepehua region 2010, 2013.

\begin{tabular}{ccc}
\hline & Index and Degree of Marginalization 2010 & Index and Degree in Human Development 2013 \\
\hline Hidalgo & 0.661 High & 0.748 low average levels \\
Huehuetla & -0.6818 Very High & 0.611 low average levels \\
Tenango de Doria & -0.388 Average & 0.644 low average levels \\
San Bartolo Tutotepec & -1.745 Very High & 0.589 low average levels \\
\hline
\end{tabular}

Own calculations based on data from the Consejo Nacional de Población, 2010 and the Programa de las Naciones Unidas para el Desarrollo, 2013.

Table 3. Otomí-Tepehua Region, 1999. Participation in the Gross added census of economic establishments by activity sector.

\begin{tabular}{ccc}
\hline Economy Sector & Percentage \\
\hline Tertiary & 90.7 \\
Secundario & 8.6 \\
Primary & 0.7
\end{tabular}

Own calculations based on data from the Instituto Nacional de Geografía e Informática, 2004. Sistema de Cuentas Nacionales de México. Producto Interno Bruto en los municipios del estado de Hidalgo. 
The characteristic of the vulnerable economic base can be seen in Table 4, which shows the most important sub-sectors in order of importance: retail trade, hotels and restaurants and wholesale trade.

In turn, the clearest evidence of the predominance of productive units in the economy can be seen by taking a tour through the main roads of the region, since small miscellany shops stand one behind the other and this suggests that there is almost one per family.

In 2011, the state of Hidalgo had a total area of 2,098,700 hectares, of which $30 \%$ were for agricultural use. On this date, the agricultural area was 588,741 hectares, of which $77.5 \%$ was established in rain-fed areas and the rest in irrigated areas.

Comparing the cultivation of maize and beans in the Otomi-Tepehua region to total agricultural cropland in the state of Hidalgo surface shows that this economic activity is very low. But at a regional level, their impact is most evident and observed the following order of importance in Huehuetla, San Bartolo Tutotepec and Tenango de Doria (see Table 5).

In this regard, a relevant additional data indicate that in the production of basic grains (corn and beans) seem to have a fundamental role in Hueheutla, unlike what happens in San Bartolo Tutotepec and Tenango de Doria, places with greater dependence to restock these products at the city market of Tulancingo (Hidalgo).

In turn, the same order of importance is seen in the destruction of the forest, that is, areas eroded by agriculture are most evident in Huehuetla, San Bartolo Tutotepec and then Tenango de Doria.

According to the Hidalgo Coffee Council (2014), in 2013, the Otomi-Tepehua region emerged as the leading producer of organic coffee in the state of Hidalgo, helping Mexico in this year to be the leading producer of organic coffee worldwide. Meanwhile, the country ranked fifth in order of the largest coffee producers in general, standing out only behind Brazil, Vietnam, Colombia and Indonesia.

In the study region, coffee is an important economic activity which has invested a huge capital and effort, but to date, this option has not helped to ease poverty, mainly because their cultivation may be done effectively in a thin strip; that is, either very high or very low altitude above sea level; inclusive, it is because the price of coffee is locally controlled by the caciques. That is, the production of this product has neither solved the problem of poverty, nor the destruction of the forest.

Table 4. Otomí-Tepehua Region, 1999. Participation in the gross added census of economic establishments by tertiary sector.

\begin{tabular}{lc}
\hline Subsector of the economy & Percentage \\
\hline Retail Trade & 61.5 \\
Hotels and Restaurants & 11.3 \\
Wholesale Trade & 10.3 \\
Beauty parlor and Barber shops & 3.3 \\
Maintenance & 2.1 \\
Professional Services & 1.9 \\
Transport & 0.3 \\
\hline
\end{tabular}

Own calculations based on data from the Instituto Nacional de Geografía e Informática, 2004. Systemas de Cuentas Nacionales de Mexico. Gross domestic product in the municipalities of the State of Hidalgo.

Table 5. Municipalities in the Otomí Tepehua Region, 2011. Cultivated area with corn (absolute hectares and percentage).

\begin{tabular}{cccccc}
\hline & Corn & $\%$ & Beans & \% & Surface in Hidalgo \\
\hline Otomí-Tepehua Region & 9,686 & 1.7 & 527 & 0.1 & 558,741 \\
Huehuetla & 4,650 & 0.83 & 378 & 0.7 & 558,741 \\
Tenango de Doria & 2,736 & 0.41 & 70 & 0.01 & 558,741 \\
San Bartolo Tutotepec & 2,300 & 0.41 & 79 & 0.01 & 558,741 \\
\hline
\end{tabular}

Own calculations based on data from the Instituto Nacional de Geografía e Informática, 2004. 
Nationally, in 2013, Hidalgo stood out in fifth place among the main coffee producers. In this regard, the Hidalgo Coffee Council (2014) predicts the existence of a high risk of loss of coffee harvest in the coming years due to the presence of the screwworm plague.

In addition, as shown in Table 6, we wanted to investigate official data on tree planting. In this case, in the Otomi-Tepehua region highest rates are observed with respect to the national and state levels, given that, in two of the three municipalities that make up the region, distributed levels of trees planted per capita is almost seven times higher in San Bartolo Tutotepec and two more in Huehuetla, which may be due to the residents' concern about the destruction of large forest areas, most obvious situation in San Bartolo and Huehuetla Tutotepec with respect to Tenango de Doria. In this regard, there is no data available for timber production, or forestry, which with certainty occurs surreptitiously.

In 2014, in a survey of a non-random sample of small landowners of agricultural parcels in the 3 municipalities of study, it was found that there is a concern for the destruction of the forest. The towns included in the survey were: Cerro Grande (Tenango de Doria), El Bosque (Huehuetla), Salto del Agua (Huehuetla), Agua Escondida (San Bartolo Tutotepec), Los Alamos (San Bartolo Tutotepec), Monte Grande (San Bartolo Tutotepec) The Cojolite (San Bartolo Tutotepec) and Piedra Larga (San Bartolo Tutotepec).

As we have seen, it is noteworthy that there is a real concern due to social changes and economic dynamics that cause the destruction of forest areas due to the production of corn and beans.

From what we can observe, in 2014, in the localities of higher marginalization in Hidalgo, located in the Otomi-Tepehua region, land tenure is mostly privately owned. But also, in this place, through direct observation, we were able to perceive the symbiotic relationship between caciques and farmers. It is the latter who practice smallholding, characterized by growing corn and beans in slopes of high slope, due to the need to provide food at low cost.

To close this section, with Figures 1-5 we show the ecological impact of milpa cultivation on slopes with rugged hillsides and populated with forest or jungle. Figure 1 shows the biological richness of the study area and its capacity to produce water and oxygen, which, as we indicated in an insistent manner, is affected by the practice of family agriculture subsistence, Figure 2. And such activity seen in the regional context provides us with the extent of ecological damage (Figure 3). Finally, Figure 4 and Figure 5 make clear that in the area of studies we have a process of desertification because the current agricultural practices imply to leave the soil without vegetation cover for at least three months until the fallow and planting cycle is repeated.

\section{Conclusions}

It is no novelty to point out that in Mexico, forest areas have been decreasing alarmingly in recent decades. However, we must specify that in the context of recent changes in the less developed capitalist societies, there are a number of difficulties experienced by the population that resides there. Doing nothing at the local level, in 30 years, in the Otomi-Tepehua region, a vast desert extension will be visible, despite maintaining the current conditions of intense rainfall, worsening the living conditions of its residents, increasing poverty by direct reduction of the quantity and quality of agricultural land, and, above all, for most people in central part of the country, there would be the greatest negative impact with the reduction of water and oxygen, a priority matter in the next years.

Also with the available data, we have confirmed that with the dynamics of the economy and the current social change, the forest and the jungle are being destroyed with the demand of land for growing corn and beans. In this regard, the absence of available data on the benefits of timber sale, it is certain that this activity is carried out surreptitiously and without control. Because of which, the degradation of nature is growing on account of the main economic activities of the population.

The region with the most social backwardness in the state of Hidalgo and changes in the economy are causing not only the deterioration of the environment and the destruction of ecological systems, so does inequality,

Table 6. Municipalities in the Otomí-Tepehua Region, 2010. Planted trees distributed per inhabitants.

\begin{tabular}{cccccc}
\hline & Huehuetla & San Bartolo Tutotepec & Tenango de Doria & Hidalgo & México \\
\hline Planted trees per inhabitants. & 2.4 & 8.0 & 0.9 & 1.5 \\
\hline
\end{tabular}

Own calculations based on data from the Instituto Nacional de Geografía e Informática (Mexico in figures, several years). 


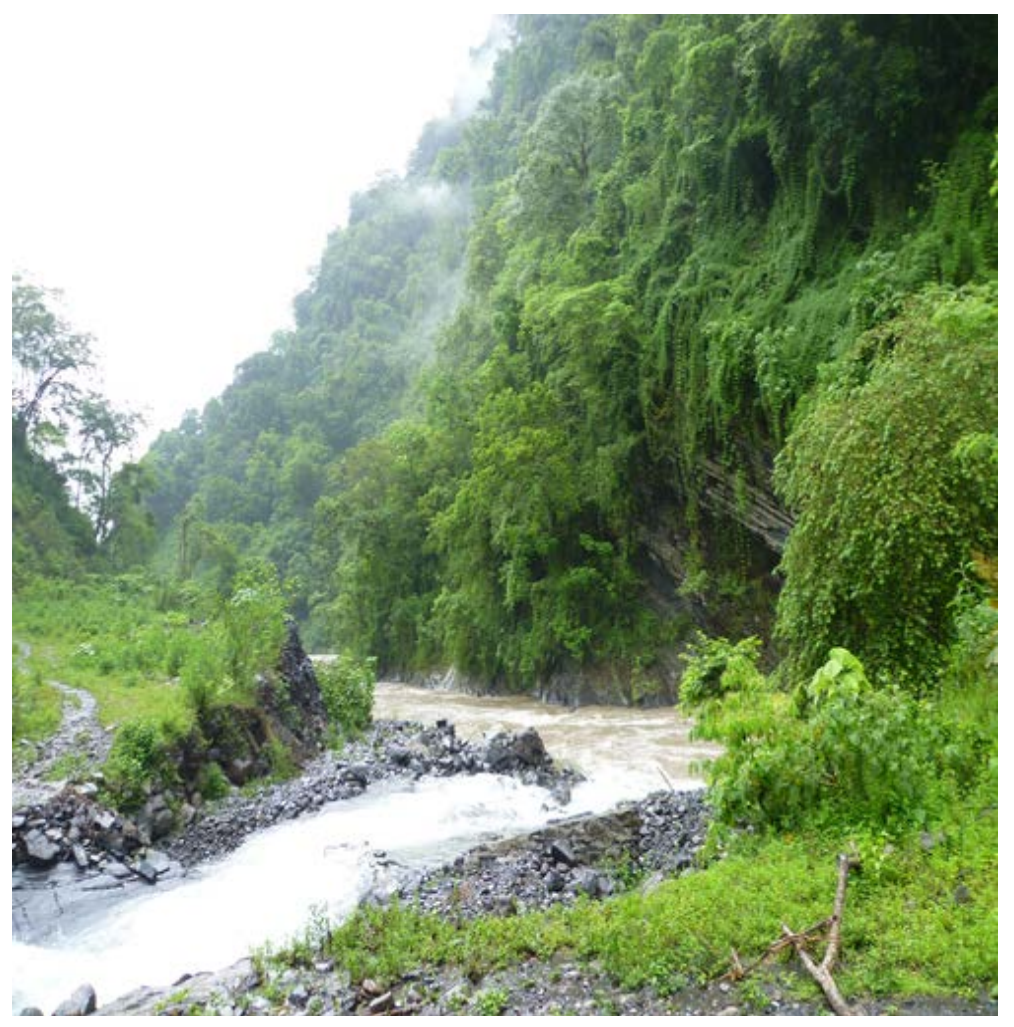

Figure 1. Biotic wealth in the study area. Santiaguito river, San Bartolo Tutotepec, Hidalgo, México (Quezada, 2014).

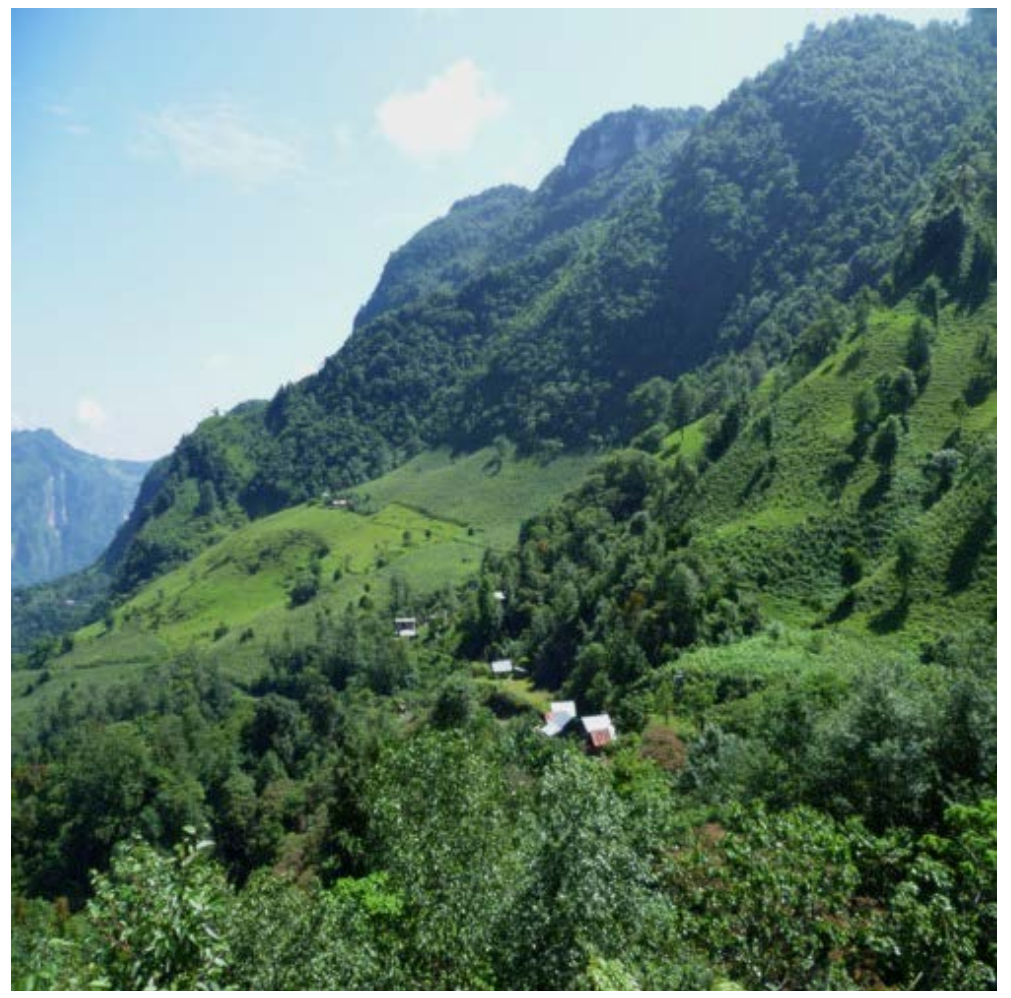

Figure 2. Milpa vs. forest. La Cruz, San Batolo Tutotepec, Hidalgo, México (Serrano, 2015). 


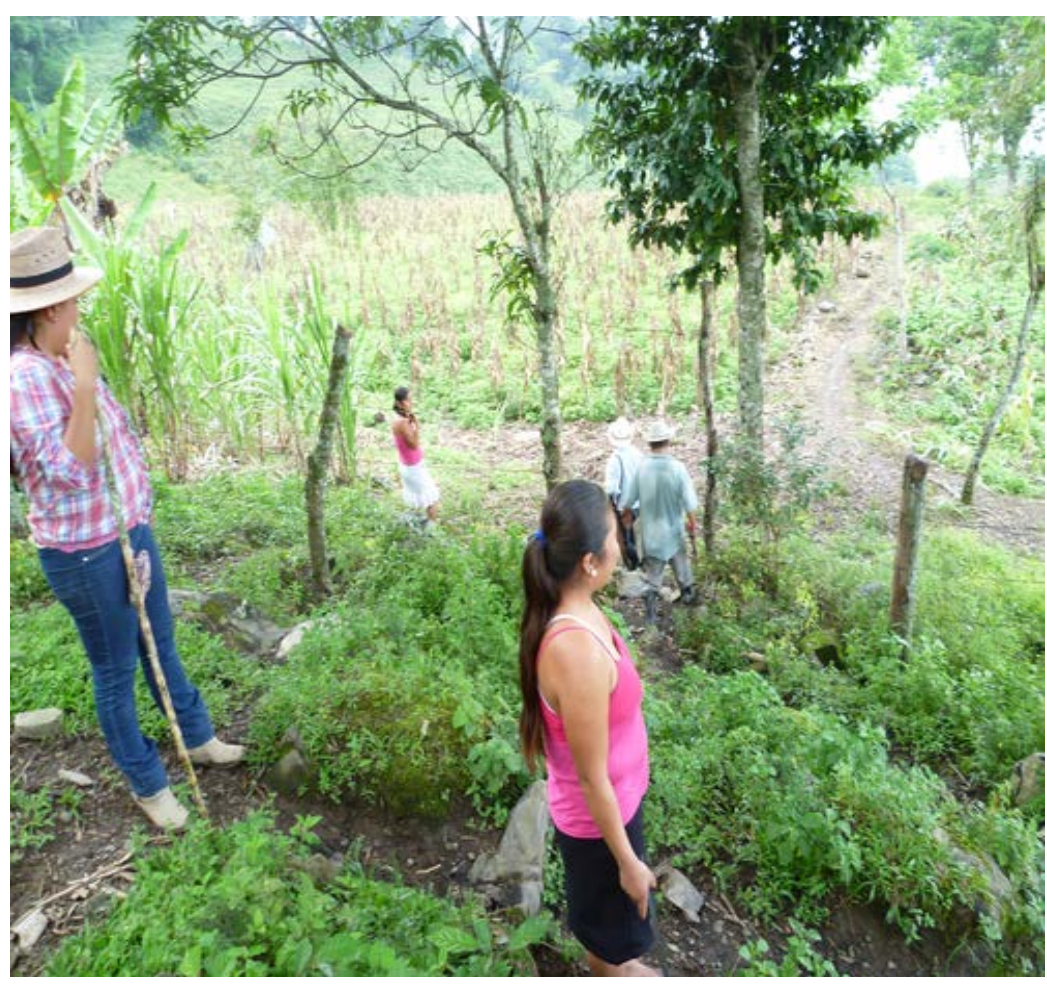

Figure 3. Agriculture system for home consumption. Family milpa. San Jerónimo, San Bartolo Tutotepec, Hidalgo, México (Quezada, 2014).

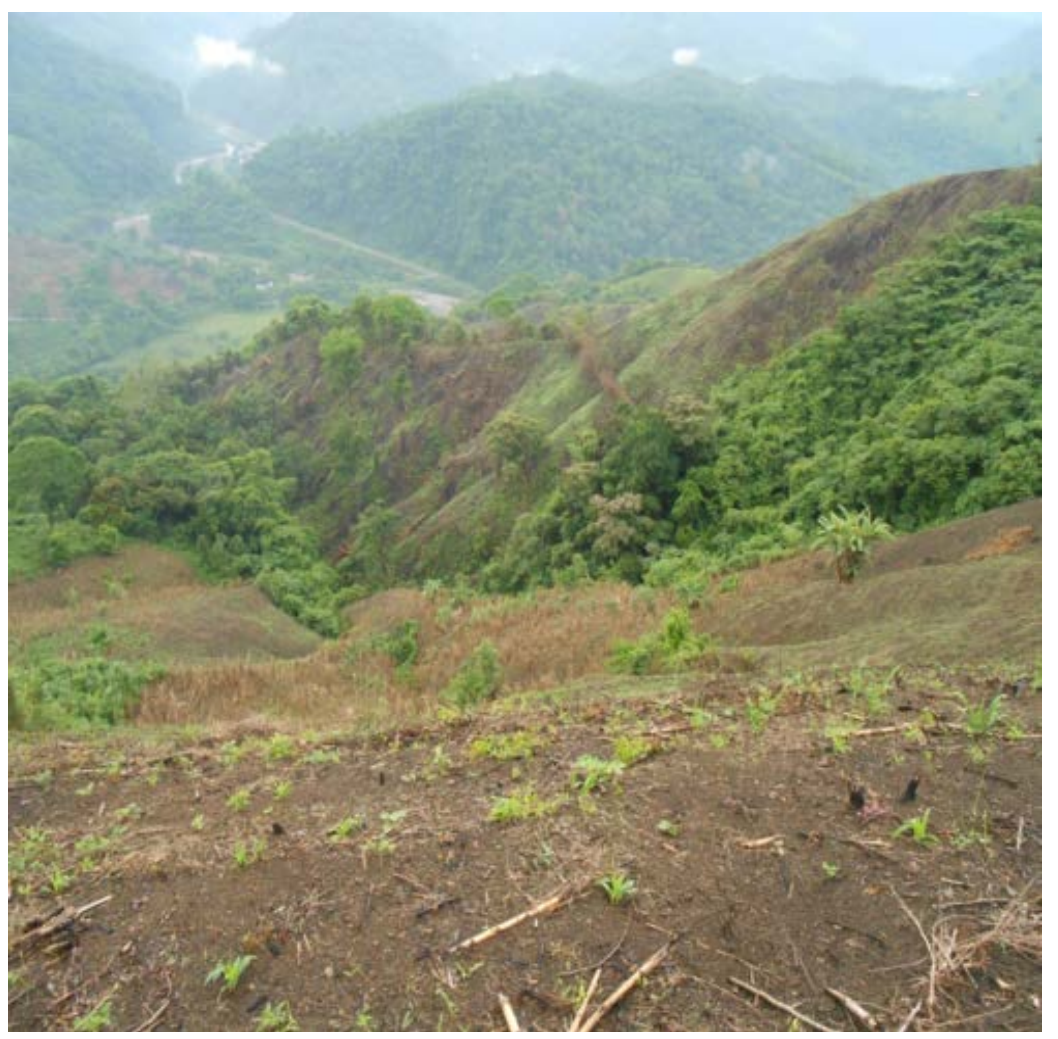

Figure 4. Plots after the harvest of a milpa. Juntas Chicas, Huehuetla, Hidalgo, México (Serrano, 2014). 


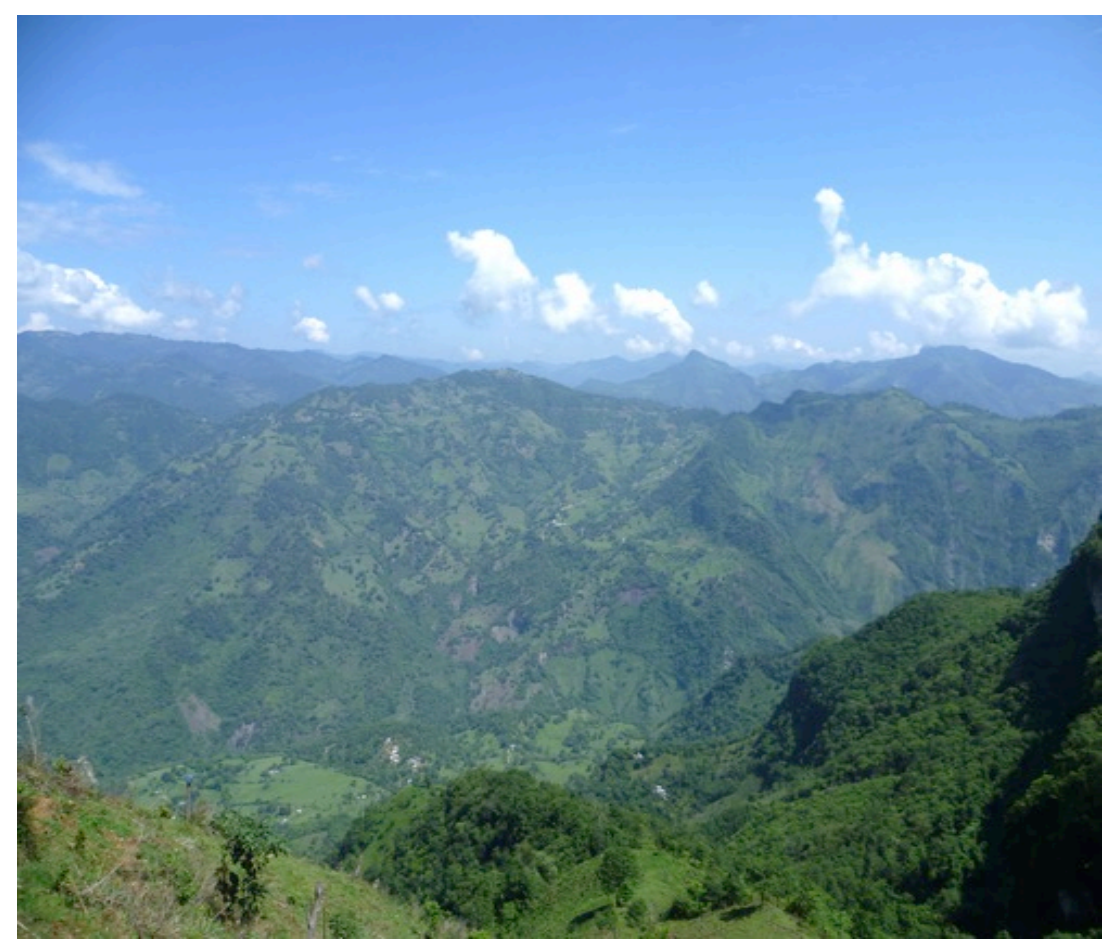

Figure 5. Population impact in the forest. Santa Cruz, San Batolo Tutotepec, Hidalgo, México (Serrano, 2014).

understood as the inability of the population to participate in the new organizational forms of money and employment multiplication, features that reduce the chances of life quality.

When the value of money determines the performance of economic activities of people, environmental degradation prevails over the preservation of scarce resources and jeopardizes their enjoyment of future generations, a matter which should be taken care of to reverse the damage.

Our proposal demands the design of a comprehensive development plan for the Otomi-Tepehua region. Our starting point suggests following Spierenburg and his colleagues, to try to boost the important economic activities of local residents while forest extensions increase. After all, in the study area there are conditions similar to those of Bhutan, including the important one: people’s awareness that they are destroying the forest.

We also agree that in the municipalities of study it is essential to continue planting corn and beans to not depend on the supply from cities. But, the multiplication of the grains must depend on not altering the goods and existing ecosystems. Based on the study, it is clear that the territory must have an order to regulate the cultivation of agricultural products in high slope areas.

In the world there is a consensus that the poor inhabit the areas of the highest biodiversity, where also the most fragile ecosystems are located. According to Jeffrey McNeely and Mohan Munasinghe [14], this region is home to $80 \%$ of the population in Latin America, $60 \%$ from Asia and 50\% from Africa. In addition, in their territory, infant mortality and malnutrition reach extremely high levels. Though data generalizes a global situation, regionally, in the Sierra Otomi-Tepehua, the theory is consistent and allows us to predict that, over the course of several decades extreme poverty will persist and the extinction of ecosystems will continue.

In this opportunity, we were able to observe the crunch of social change in the richest biotic region in the state of Hidalgo and greater social backwardness. By putting the development of important agricultural economic activities of the population in the center stage, we noticed the best alternatives for local residents, as long as they can organize themselves to gain control of their territory and participate in the development of a proposal which seems to be the best for everyone.

There is a lot to be done in the Otomo-Tepehua region, and a titanic task awaits the university whenever one is working in the line of social responsibility, since, now, it is increasingly important to align the economic development to the social development environment with the environment development. 


\section{Acknowledgments}

This work is part of the Proyecto PRODEP-UAEH Potencialidades de desarrolloenlocalidades de muyaltamarginaciónen el estado Hidalgo 2014. We appreciate the collaboration given by the local people from villages during field work.

\section{References}

[1] Organización de las Naciones Unidas (1972) Conferencia de las Naciones Unidas Sobre Medio Ambiente. Estocolmo, Suecia.

[2] Grove, J. and Burch, W. (1997) A Social Ecology Approach and Applications of Urban Ecosystem and Lanscape analyses: a Case Study of Baltimore, Maryland. Urban Ecosystems, 1, 259-275. http://www.esf.edu/cue/documents/grove-burch_socecolapp-urbecosys_1997.pdf http://dx.doi.org/10.1023/A:1018591931544

[3] Boulding, K. (1966) The Economics of the Coming Spaceship Earth. In: Jarrett, H., Ed., Environmental Quality in a Growing Economy, Resources for the Future/Johns Hopkins University Press, Baltimore, 3-14.

[4] Cantú, P. (2012) El axioma del desarrollo sustentable. Revista de Ciencias Sociales, III, 83-91. http://www.redalyc.org/pdf/153/15325492007.pdf

[5] Ayres, R.U. (2008) Sustainability Economics: Where Do We Stand? Ecological Economics Review, 67, 281-310. https://sustainability.water.ca.gov/documents/18/3407732/Sustainability+economics+Where+do+we+stand.pdf

[6] Uclés, D. (2006) El valor económico del medio ambiente. Ecosistemas: Revista científica y técnica de ecología y medio ambiente, 15, 63-68.

[7] Left, E. (1998) Saber Ambiental: Sustentabilidad, Racionalidad, Complejidad, Poder, Ed. Siglo XXI, PNUMA, CIICH, México.

[8] Martine and Diniz (2015) Economía, Sociedad e Medio Ambiente en el siglo 21: Triple vertiente o trilema de la sostenibilidad. Revista Brasileira de Estudios de Población, 32, 433-460. www.rebep.org.br/index.php/revista/issue/download/58/pdf_652

[9] Leff, E. (2004) Racionalidad Ambiental, la reapropiación social de la naturaleza, Ed. Siglo XXI, México.

[10] Ponting, C. (1990) A New Green History of the World: The Environment and the Collapse of Great Civilizations. Vintage Books, London.

[11] Lakshmana, C.M. (2013) Population, Development, and Environment in India. Journal of Population Resources and Environment, 11, 367-374. http://dx.doi.org/10.1080/10042857.2013.874517

[12] Spierenburg, P., Karma, T. and Rai, D.S. (2005) Salvando el bosque mediante la intensificación de la ganadería. Leisa-Revista de agroecología, 20, 35-37.

[13] Tetreault, V. (2009) Pobreza y degradación ambiental. Las luchas de abajo en dos comunidades del occidente de Jalisco: Ayotitlán y La Ciénega. Universidad de Guadalajara, México.

[14] Munasinghe, M. and McNeely, J. (Eds.) (1994) Protected Area Economics and Policy: Linking Conservation and Sustainable Development. World Bank, Washington DC.

http://www-wds.worldbank.org/external/default/WDSContentServer/WDSP/IB/1994/01/01/000009265 39707161435 58/Rendered/PDF/multi page.pdf 